Original Research Paper

\title{
Use of Plectranthus amboinicus in Feeding Fattening Pigs
}

\author{
${ }^{1}$ Angel Roberto Sánchez, ${ }^{1}$ Mayte Madelaine Vega Tinoco, ${ }^{1}$ Esmeralda Dioselina Pimbosa Ortiz, \\ ${ }^{1}$ Jordy Daniel Cordovilla Loaiza, ${ }^{1}$ Mercedes Milena Jordán Romero and ${ }^{2}$ Ion Pérez Baena
}

${ }^{I}$ Faculty of Agricultural Sciences, Universidad Técnica de Machala, Machala-Ecuador, Research Group on Food Production and Animal Health (GIPASA), Seedbed for Research in Animal Production (SIPA), Spain ${ }^{2}$ Department of Animal Science. Universitat Politècnica de Valencia, Valencia-Spain

\section{Article history}

Received: 28-06-2021

Revised: 10-09-2021

Accepted: 02-10-2021

Corresponding Author: Angel Roberto Sánchez Faculty of Agricultural Sciences, Universidad Técnica de Machala, Machala-Ecuador, Research Group on Food Production and Animal Health (GIPASA), Seedbed for Research in Animal Production (SIPA), Spain

Email: arsanchez@utmachala.edu.ec

\begin{abstract}
This research was developed at the Hacienda "Los Hermanos" belonging to the company Super Mac, located in Balao canton, Guayas province, coastal region of Ecuador, the purpose of this study was to evaluate the effect of the inclusion of ground dehydrated P. amboinicus in the feed of fattening pigs on their productive parameters and antibacsterial response. Four treatments were distributed, each one with 20 animals, regardless of sex for a total of 80 pigs, starting at 49 days of age and ending the experiment at 105 days, considering each pig as an experimental unit. A Completely Randomized Design (CRD) was used, with the following treatments: Treatment 1 , control (T1), to which a commercial diet was administered, T2, T3, T4 to which $0.25,0.50$ and $0.75 \%$ of the dehydrated $P$. amboinicus was added to the commercial diet, respectively. For data analysis, the statistical program Statgraphics Centurion XV.I ® was used, applying a one factor Analysis (ANOVA) and to establish the differences between the means obtained, the procedure of the multiple comparison of Bonferroni was used with a $95 \%$ level of confidence, the variables evaluated were: Live weight gain and accumulated feed consumption in $\mathrm{kg}$, feed conversion, mortality in percentage, total microbial flora and total coliforms in CFU. The results showed that, for the variables of productive parameters, there is no statistically significant difference, although there is a difference for the variables of total coliforms and total microbial flora when compared with T1, especially at the end of the experiment. As a conclusion there is an effect at the level of the antibacterial response, showing a positive correlation, the higher the percentage of dehydrated P. amboinicus included the greater efficacy in the control of CFUs. No mortality was found during this experiment.
\end{abstract}

Keywords: Productive Parameters, Antibacterial Response, Carvacrol, Thymol

\section{Introduction}

The Ecuadorian pig market stands out for the demand for lean meats, which are generally obtained with the crosses of strains that are currently provided by companies that distribute genetics nationwide, highproduction animals as well as high nutritional demand and that have repercussions in the improvement of meat products (Flores et al., 2015). Among the most used lines are Landrace and Pietrain (Caicedo and Flores, 2020).

The Landrace swine line refers to a lean breed of Danish origin (Xiao et al., 2018), which has a rapid growth, selected for its high carcass yield (Tan et al., 2017). Among the reproductive characteristics of this breed, there are approximately 10 live piglets per parturition, 342 days old at the first parturition and a weaning-mating interval of 16 days, the piglets can weigh
$1.4 \mathrm{~kg}$ at birth (Miranda-Yuquilema et al., 2018a). In good conditions of handling and feeding, the females of this breed can reach weights of $300 \mathrm{~kg}$ while the males can weigh up to $400 \mathrm{~kg}$ (Bencomo, 2010).

The Pietrain line of pigs has its origin in Belgium, it is considered one of the most muscular pig breeds in the world (Guachamín et al., 2018), however, it has a low prolificacy and its number of offspring per litter and growth are lower to those of the Landrace breed (Blanco et al., 2019), with approximately 9 live piglets per birth and 7 8 weaned piglets per birth, so their production is more oriented towards obtaining products, with this in account, Pietrain pigs have a yield of between 72 and $75 \%$ and an approximate feed conversion of 2.6 (Oñate et al., 2020). However, other authors state that the feed conversion of this breed does not exceed the amount of 1.48 (Aragadvay, et al. 2016). The females of this breed can 
reach weights of $260 \mathrm{~kg}$ while the males weigh between 280 and $300 \mathrm{~kg}$ (Carrero, 2005).

In such a way, fattening farms are characterized by handling maternal and paternal lines crosses (F1), which is how a product is obtained that responds to current market demands (Caicedo et al., 2020).

So, the growing demand and requirements in the food sector has driven a constant update in the industry, affecting the final product, due to the importance of a responsible and quality diet (Miranda-Yuquilema et al., 2018b). Currently, research with feed formulas stands out for using innocuous alternatives that infer in the final product, especially in the animal carcass, due to the search for alternatives to replace the synthetic additives present in the feed, which often result be harmful to the health of consumers, if not managed properly, as is the case with the use of Growth-Promoting Antibiotics (GPA) (Paredes et al., 2020).

The European Commission in 1997 established a surveillance program on the emergence of bacteria resistant to antibiotics used as feed additives in pigs and broilers in slaughterhouses of six member states of the European Union and as of January 2006 the use of growth promoters in animal feed (Espinoza et al., 2019). The list of these prohibited substances included bacitracin, oleandomycin, spiramycin, virginiamycin, flavophospholipol, erythromycin, tetracyclines, penicillins, neo-mycin, hygromycin B and tylosin (Ardoino et al., 2018).

These synthetic additives have been very useful and beneficial in animal production, but currently they are generating microbial resistance due to their misuse use when trying to prevent and control pathogens that produce livestock diseases, causing, in some cases, a tolerance to the drugs (Urbano and Velásquez, 2020), which has led the producer to increase the dose or apply stronger pharmaceutical treatments, affecting the animals by the possible toxicity of the drug and complicating the situation by not respecting withdrawal times, generating possible residues in meat and/or other products, thereby compromising the health of the consumer (Paredes et al., 2020).

Due to the above, it has been driven to carry out research on natural replacement alternatives to the synthetic additives currently used in the feed aiming to provide protection to the animals against diseases but that do not affect the health of the consumers; among which the products made from medicinal plants stand out (Chuchuca et al., 2016), due to the various benefits they offer, such as presenting a lower risk to livestock and consumer's health compared to the chemical substances commonly used in the formulation of rations (Pujada et al., 2019). For this reason, the use of products of plant origin with therapeutic properties tries to take advantage of the active principles present in them, whose natural pharmacological activity is beneficial, although in certain cases, it could be harmful if it is not properly controlled (Chuanshang et al., 2017).
Taking into account the previous paragraph, Plectranthus amboinicus is among the most prominent plant origin products with pharmaceutical properties, which is a plant belonging to the Libiatae family, found in tropical and subtropical areas of Asia and Africa as well as in countries of South America, where is known as oreganon (Menendez and Pavón, 2018). Oreganon has antioxidant capacity, since it has a protective effect on the cellular components of biological importance, furthermore it contributes to maintain a balance in the intestinal flora, thus controlling pathogenic microorganisms due to its antibacterial capacity and, indirectly stimulates the consumption of food, which allows to reduce the uncontrolled use of drugs while offering a safe and quality food for human consumption (Gupta et al., 2016).

In the livestock area, specifically in animal production, oreganon can be used in different ways (Ribiero et al., 2018). A series of components that have therapeutic biological capacity can be extracted from this plant, showing good results when used in livestock management (Languido et al., 2020). Thus, in research carried out by Mernandez et al. (2015) who evaluated the use of oreganon essential oils (thymol and cinnamaldehyde), in the diet of fattening pigs, a greater live weight gain was obtained in the treatments that included those products in the feed, when compared to the control group, also a decrease in the incidence of diarrhea was reported.

Due to the above, the objective of this study was to evaluate the effect of adding ground dehydrated $P$. amboinicus in the feed of fattening pigs, on their productive parameters and antibacterial response.

\section{Materials and Methods}

\section{Research Location}

This research was carried out at the Hacienda "Los Hermanos" of the Super Mac company, which is located at kilometer 123 on the way to Guayaquil, Guayas province, coastal region of Ecuador, the geographical coordinates are: -79.8333 longitude, -2.91667 latitude and an altitude of 5 meters above sea level. Its temperature fluctuates between 22 and $35^{\circ} \mathrm{C}$.

\section{Field Methodology}

All the established norms for pig handling in open houses described in the Guide of Good Swine Practices (GPP), AGROCALIDAD-ECUADOR were applied. A pressure washer was used for cleaning the rearing cages as well as the application of a mixture of liquid disinfectants with water; a mixture of lime and glue was used for the walls as a means of disinfection, cleaning and whitening. The animals were weaned at 21 days and to increase the challenge, no antibiotic was applied as a preventive method in the respective management.

For the experiment, 80 (49-day-old) pigs of Topic Landrace and Pietrain breeds (F1) were taken and randomly 
distributed in the different treatments in the rearing area, without taking into account their sex; establishing four groups, it was contemplated that each animal would represent an experimental unit for the analysis of the weight gain variable. For feeding the animals, a commercial diet (Wayne company "Molinos Champion"), isoprotein and isoenergetic was used (Initial Phase 2 Feed: PC 19 - 22\%, GC 2 - 10\%, FC 1 - 4\%; Growth Feed: PC 19-21 \% GC 2$10 \%$ FC $1-5 \%$ ); which was under the specifications of the treatments (commercial feed with and without GPA); at day 70 , the animals were transferred to the fattening area to continue with the experiment. Each week the feed consumption and the respective surplus were recorded, as well as the live weight of the animals. Water consumption was ad libitum. The investigation lasted 56 days (8 weeks).

To obtain dehydrated Plectranthus amboinicus, the fresh leaves of the plant were taken, the cutting of which was carried out every 52 days according to the technical recommendations of Ayala et al. (2006) and were placed in each of the dehydrating trays (turbo dehydrator "Ronco ${ }^{\circledR}$ " EZ-Store 5 trays) and left there for $24 \mathrm{~h}$ at $63^{\circ} \mathrm{C}$., after this time, the sample stabilized on the counter until it reached room temperature for 48 $\mathrm{h}$ and then proceeded to grind. The amount of the necessary dehydrated Plectranthus amboinicus for each treatment was weighed daily and the corresponding feed (without GPA) that the animals consumed was included. For weighing, a CAMRY scale (model EK9332-F302) with a margin of error of $\pm 1 \mathrm{~g}$ was used (Fig. 1-3).

\section{Laboratory Methodology}

In order to determine total microbial flora and total coliforms, feces of the animals were collected directly, in such a way that two samples were taken per treatment with a total of 8 , well identified and labeled. The first feces collection was at the beginning of the experiment (day 49), the second, on day 74 and the third on day 105, at the end of the experiment. For laboratory tests, the dilution was based on the methodology described by Chuchuca et al. (2016), the culture media were prepared at $100^{\circ} \mathrm{C}$. For total bacteria, the petri dishes were left to rest in the autoclave for 24 to $48 \mathrm{~h}$ at a temperature of $37^{\circ} \mathrm{C}$.

\section{Experimental Design}

A Completely Random Design (CRD) was used, in such a way that four groups of 20 animals each were created, regardless of sex. The treatments were the following: Treatment 1, control (T1), which was administered a commercial diet (with GPA), T2, T3 and T4 to which $0.25,0.50$ and $0.75 \%$ of dehydrated Plectranthus amboinicus were added, respectively (in a commercial diet which did not contain GPA).

\section{Variables Evaluated}

\section{Live Weight Gains of the Animals ( $K g$ )}

Starting from an initial weight of the pigs, the data of each of the treatments was recorded weekly, in such a way that the weight gain of each of the animals could be identified. This variable was quantitative and to obtain it, a TRU-TEST electronic scale was used with a total capacity of $2000 \mathrm{~kg}$ and a margin of error of $0.50 \mathrm{~kg}$. Recording 640 data (4 Treatments x 20 experimental units $\mathrm{x} 8$ weeks). Applying the following formula.

Live Weight Gain $(\mathrm{kg})=$ Live Weight $($ Recorded $)$ Live Weight at the Beginning of the Experiment.

\section{Cumulative Feed Intake ( $\mathrm{Kg}$ )}

The amount of commercial feed given to each group of animals in their respective feeders was recorded and at the end of the week, the excess was weighed. This variable was of a quantitative type. The recorded data were 32 (4 Treatments $\mathrm{x} 8$ weeks). The applied formula was:

\section{Cumulative feed Intake $(\mathrm{kg})=$ Feed of fered - Leftover feed}

\section{Feed Conversion Ratio}

This data results from the division of two variables: the feed consumed divided by the weight gain of the animals, this value being of a quantitative type. 32 data were recorded (4 Treatments $x 8$ weeks). The applied formula was:

$$
\text { Feed conversion ratio }=\frac{\text { Total feed Consumed }(\mathrm{kg})}{\text { Final live Weight }(\mathrm{kg})-\text { Initial live Weight }(\mathrm{kg})}
$$

\section{Mortality (\%)}

A weekly record was kept of all animal losses throughout the study, it was expressed as a percentage and it was a quantitative variable. It was calculated using the following formula:

$$
\operatorname{Mortality}(\%)=\frac{\text { Numberof pigs }(\text { start })-\text { number of pigs }(\text { end })}{\text { Number of Pigs }(\text { start })} \times 100
$$

\section{Total Microbial Flora and Total Coliforms}

To determine these variables (either total microbial flora and total coliforms), 2 samples were taken per treatment at the beginning, middle and at the end of the experiment, to count Colony Forming Units (CFU) in PCA and Mac Conkey media cultures using microbial plates. 48 data were obtained (4 Treatments x 2 variables $\mathrm{x} 2$ replicas $\mathrm{x} 3$ times).

\section{Statistical Analysis}

Taking as a guide the book by Blasco (2010) corresponding to the analysis of experimental data for final degree projects, the assumptions of normality and homogeneity were verified, submitting the data to an analysis 
Angel Roberto Sánchez et al. / American Journal of Animal and Veterinary Sciences 2021, 16 (4): 303.311 DOI: 10.3844/ajavsp.2021.303.311

of variance (ANOVA) for weight gain, total microbial flora and coliforms totals, while for the variables feed consumption and feed conversion ratio, a population comparison statistic was used. The method used to discriminate between the means was the Bonferroni multiple comparison procedure to establish the possible existence of differences at a confidence level of $95 \%$. The statistical program used was Stat graphics Centurion XVI.

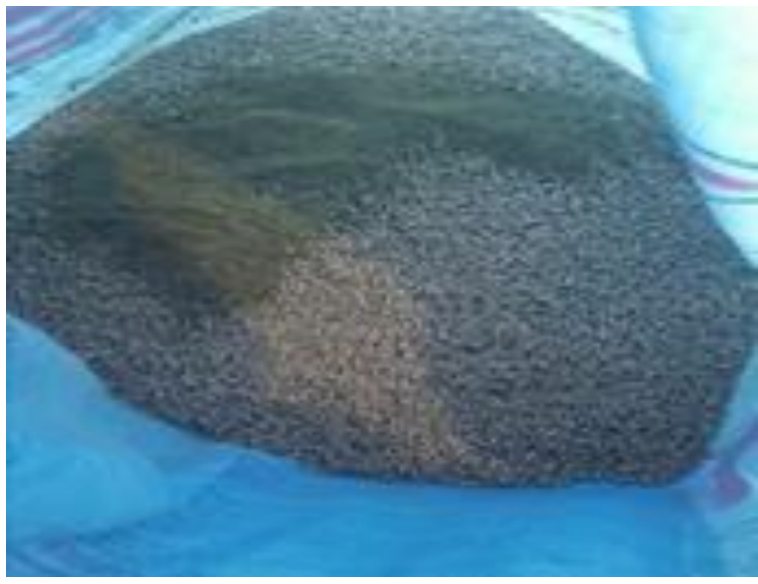

Fig. 1: Commercial feed with dehydrated P. amboinicus

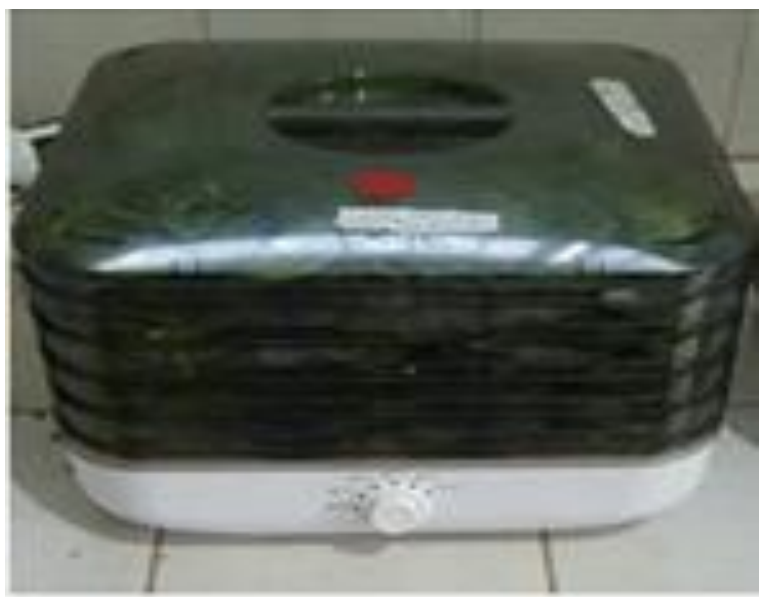

Fig. 2: Layout of the trays with P. amboinicus leaves loaded in the turbo dehydrator

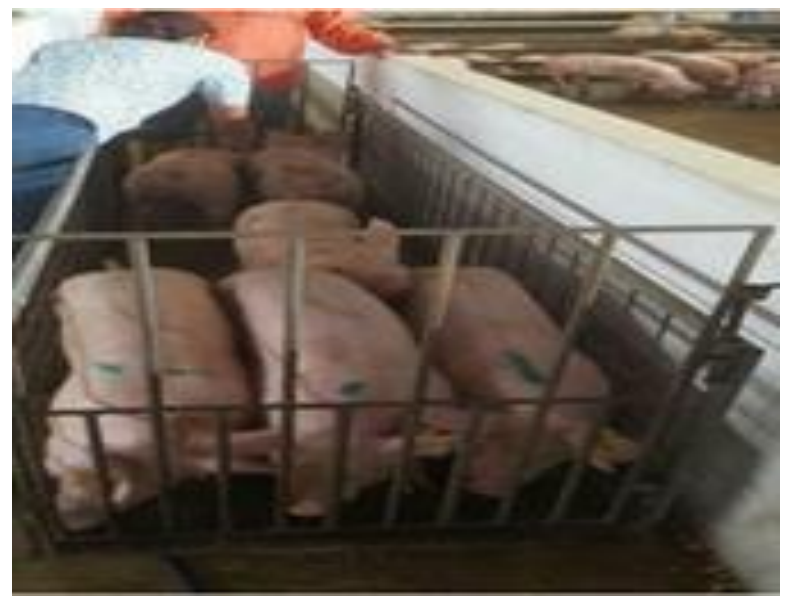

Fig. 3: Weighing the pigs in the fattening area 


\section{Results}

\section{Live Weight Gain}

\section{Cumulative Feed Intake, Feed Conversion Ratio and Mortality}

Table 1: Live weight gain $(\mathrm{kg})$ from day 56 to 77

\begin{tabular}{lllll}
\hline Treat $^{1}$ & Day $56(\mathrm{Kg})$ & Day 63 $(\mathrm{Kg})$ & Day 70 $(\mathrm{Kg})$ & Day $77(\mathrm{Kg})$ \\
\hline 1 & $2.91 \pm 0.41^{\mathrm{a}}$ & $7.08 \pm 0.61^{\mathrm{ab}}$ & $11.05 \pm 0.87^{\mathrm{ab}}$ & $14.21 \pm 1.09^{\mathrm{ab}}$ \\
2 & $2.80 \pm 0.41^{\mathrm{a}}$ & $5.81 \pm 0.61^{\mathrm{c}}$ & $9.08 \pm 0.87^{\mathrm{c}}$ & $12.09 \pm 1.09^{\mathrm{b}}$ \\
3 & $3.54 \pm 0.41^{\mathrm{a}}$ & $7.44 \pm 0.61^{\mathrm{a}}$ & $11.73 \pm 0.87^{\mathrm{a}}$ & $14.91 \pm 1.09^{\mathrm{a}}$ \\
4 & $3.00 \pm 0.41^{\mathrm{a}}$ & $6.18 \pm 0.61^{\mathrm{bc}}$ & $9.65 \pm 0.87^{\mathrm{bc}}$ & $12.71 \pm 1.09^{\mathrm{b}}$ \\
\hline
\end{tabular}

Treat ${ }^{1}$. Treatments: 1 Control; 2, 3, 4 inclusion of dehydrated P. amboinicus at 0.25, 0.50 and 0.75\%, respectively. Day 56, 63, 70, 77: Weight gain (pigs) per week. Values are mean \pm SD. Values in the same row with different superscript letters indicate significant differences among treatments $(\mathrm{P}<0.05)$

Table 2: Live weight gain $(\mathrm{kg})$ from day 84 to 105

\begin{tabular}{lllll}
\hline Treat. ${ }^{1}$ & Day $84(\mathrm{Kg})$ & Day 91 $(\mathrm{Kg})$ & Day 98 $(\mathrm{Kg})$ & Day $105(\mathrm{Kg})$ \\
\hline 1 & $17.66 \pm 1.52^{\mathrm{ab}}$ & $22.03 \pm 2.06^{\mathrm{ab}}$ & $27.55 \pm 2.52^{\mathrm{a}}$ & $28.01 \pm 2.70^{\mathrm{ab}}$ \\
2 & $14.62 \pm 1.52^{\mathrm{b}}$ & $18.29 \pm 2.06^{\mathrm{b}}$ & $22.19 \pm 2.52^{\mathrm{b}}$ & $22.62 \pm 2.70^{\mathrm{b}}$ \\
3 & $18.15 \pm 1.52^{\mathrm{a}}$ & $22.85 \pm 2.06^{\mathrm{a}}$ & $28.07 \pm 2.52^{\mathrm{a}}$ & $28.97 \pm 2.70^{\mathrm{a}}$ \\
4 & $15.89 \pm 1.52^{\mathrm{ab}}$ & $20.21 \pm 2.06^{\mathrm{ab}}$ & $25.01 \pm 2.52^{\mathrm{ab}}$ & $25.90 \pm 2.70^{\mathrm{ab}}$ \\
\hline
\end{tabular}

Treat ${ }^{1} .:$ Treatments: 1 Control; 2, 3, 4 inclusion of dehydrated P. amboinicus at 0.25, 0.50 and 0.75\%, respectively. Day 84, 91, 98, 105: Weight gain (pigs) per week. Values are mean \pm SD. Values in the same row with different superscript letters indicate significant differences among treatments $(\mathrm{P}<0.05)$

\section{Determination of Total Microbial Flora and Total Coliforms}

Table 3: Determination of total microbial flora (CFU)

\begin{tabular}{llll}
\hline Treat. $^{1}$ & Day 49(CFU) & Day 74 (CFU) & Day 105 (CFU) \\
1 & $2.25 \times 10^{7} \pm 2.42 \times 10^{7 \mathrm{a}}$ & $9.60 \times 10^{7} \pm 1.87 \times 10^{7 \mathrm{a}}$ & $3.15 \times 10^{8} \pm 1.21 \times 10^{7 \mathrm{a}}$ \\
\hline 2 & $2.35 \times 10^{7} \pm 2.42 \times 10^{7 \mathrm{a}}$ & $3.10 \times 10^{7} \pm 1.87 \times 10^{7 \mathrm{~b}}$ & $2.15 \times 10^{8} \pm 1.21 \times 10^{7 \mathrm{~b}}$ \\
3 & $1.63 \times 10^{7} \pm 2.42 \times 10^{7 \mathrm{a}}$ & $2.18 \times 10^{7} \pm 1.87 \times 10^{7 \mathrm{~b}}$ & $9.90 \times 10^{6} \pm 1.21 \times 10^{7 \mathrm{c}}$ \\
4 & $2.76 \times 10^{7} \pm 2.42 \times 10^{7 \mathrm{a}}$ & $3.90 \times 10^{7} \pm 1.87 \times 10^{7 \mathrm{~b}}$ & $3.50 \times 10^{6} \pm 1.21 \times 10^{7 \mathrm{c}}$ \\
\hline
\end{tabular}

Trat ${ }^{1}$. : Treaments: 1 Control; 2, 3, 4 inclusion of dehydrated P. amboinicus at $0.25,0.50$ and $0.75 \%$, respectively. Day 49, 74, 105, (CFU): Days selected for sampling and determination of Total microbial flora. Values are mean \pm SD. Values in the same row with different superscript letters indicate significant differences among treatments $(\mathrm{P}<0.05)$

Table 4: Determination of total coliforms (CFU)

\begin{tabular}{llll}
\hline Treat. ${ }^{1}$ & Day $49(\mathrm{CFU})$ & Day $74(\mathrm{CFU})$ & Day $105(\mathrm{CFU})$ \\
\hline 1 & $1.85 \times 10^{7} \pm 1.63 \times 10^{7 \mathrm{a}}$ & $6.16 \times 10^{7} \pm 3.12 \times 10^{7 \mathrm{a}}$ & $1.11 \times 10^{8} \pm 2.57 \times 10^{6 \mathrm{a}}$ \\
2 & $1.36 \times 10^{7} \pm 1.63 \times 10^{7 \mathrm{a}}$ & $2.12 \times 10^{7} \pm 3.12 \times 10^{7 \mathrm{a}}$ & $9.75 \times 10^{7} \pm 2.57 \times 10^{6 \mathrm{~b}}$ \\
3 & $8.30 \times 10^{6} \pm 1.63 \times 10^{7 \mathrm{a}}$ & $1.32 \times 10^{7} \pm 3.12 \times 10^{7 \mathrm{a}}$ & $7.00 \times 10^{6} \pm 2.57 \times 10^{6 \mathrm{c}}$ \\
4 & $7.95 \times 10^{6} \pm 1.63 \times 10^{7 \mathrm{a}}$ & $1.26 \times 10^{7} \pm 3.12 \times 10^{7 \mathrm{a}}$ & $1.40 \times 10^{6} \pm 2.57 \times 10^{6 \mathrm{~d}}$ \\
\hline
\end{tabular}

Treat ${ }^{1}$. Treatments: 1 or Control; 2, 3, 4 inclusion of dehydrated P. amboinicus at $0.25,0.50$ and $0.75 \%$, respectively. Day 49 , $74,105,(\mathrm{CFU})$ : Days selected for sampling and determination of total coliforms. Values are mean $\pm \mathrm{SD}$. Values in the same row with different superscript letters indicate significant differences among treatments $(\mathrm{P}<0.05)$

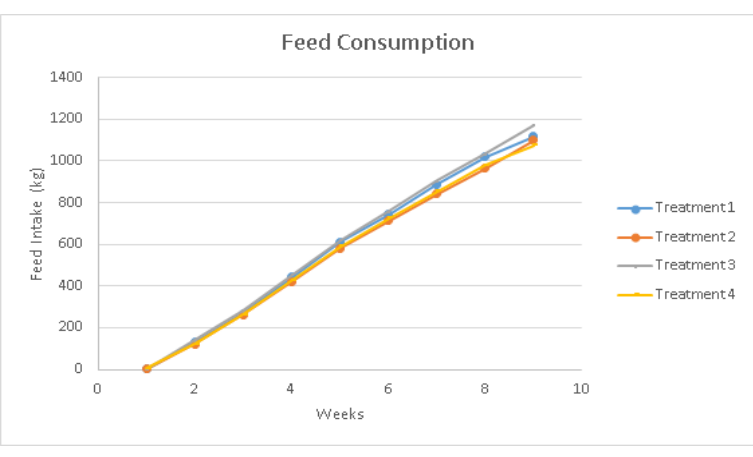

Fig. 4: Cumulative feed intake $(\mathrm{kg})$

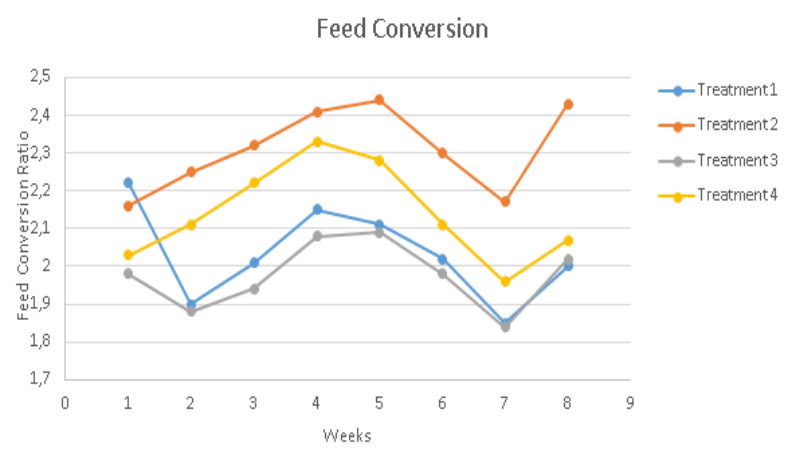

Fig. 5: Feed conversion ratio 


\section{Discussion}

\section{Live Weight Gain}

As can be seen in Table 1 and 2, there are no significant statistical differences when comparing treatments 2,3 and 4 with the control during the first and from the fourth to the eighth week, although differences can be observed in week 2 and 3 (day 63,70), showing that Treatment 2 has the lowest live weight gain when compared to the control, results that are different to those found by Chuchuca et al. (2016) in another animal species, where they used vinegar and infusion of $P$. amboinicus, to observe their effects on the productive parameters of broiler chickens (Gallus gallus domesticus), finding no statistical differences in the weekly evaluation of this variable. Similar results, if we analyze the weight at the end of the experiment but using another medicinal plant with phytobiotic effects, carried out by Caicedo et al. (2019), who administered cooked wild anise foliage in piglets, without obtaining differences in the final weight of the animals. Different results were found when applying other medicinal plants but with nutraceutical properties, as shown by Aroche et al. (2017), who used a powder mixture of the dehydrated extract of A. occidentale, M. oleifera, M. citrifolia and $P$. guajava added to the feed of fattening pigs, observing that the highest weights were reflected in the treatments containing 1 and $1.5 \%$ of this powder.

\section{Determination of Total Microbial Flora and Total Coliforms}

Table 3 shows the Total microbial flora data, where it is evident in the first sampling there is no statistical difference, however these changes and on day 74 and 105 significant statistical differences were observed. Furthermore, at the end of the experiment the tendency to reduce the total microbial flora in relation to the included percentages of dehydrated $P$. amboinicus, is maintained, especially in T3 and T4 (day 105). Results similar to those found by Chuchuca et al. (2016), who made the comparison of treatments that had oreganon, vinegar and the combination of the previous ones, showed that the control treatment had a higher amount of CFU.

In addition, a study showed that the supplementation of thymol, one of the components of Plectranthus amboinicus, was efficient in inactivating pathogenic microorganisms, without negatively altering the normal microbial flora (Escobar et al., 2020).

Table 4 shows that at day 105 , at the end of the experiment, there is a significant statistical difference among the treatments, being notorious that the highest and lowest $\mathrm{CFU}$ values for total coliforms were observed in the T1 (control) and T4, respectively. Similar results were found by Chuchuca et al. (2016), who reported that the control treatment presented a higher quantity of $\mathrm{CFU}$ with respect to total coliforms at the end of the experiment. This can be explained by the fact that, in the chemical composition of oreganon there are two known active principles that work at an antibacterial level, namely carvacrol and thymol.

\section{Cumulative Feed Intake, Feed Conversion Ratio and Mortality}

Figure 4 shows that there are no significant statistical differences in the cumulative feed intake of the animals during the study, this is explained by making a comparison that Plectranthus amboinicus has similar active ingredients as Origanum vulgare (Ashaari et al., 2020). Because Zhang et al. (2015) evaluated the inclusion of oregano in the diet of pigs with total freedom to eat and drink during the course of the study, without finding a statistically significant difference in feed intake.

Figure 5 indicates there are no significant statistical differences among the treatments during the 8 weeks of the study. These results differ from those obtained by Baca and Ampuero (2019), who evaluated the effect of the inclusion of oregano's essential oil in the feed of weaned piglets and obtained the highest value in the control treatment, thus showing a favorable effect on the feed conversion rate when compared to the treatments having the essential oil, In another research using the oreganon plant carried out by Cheng et al. (2018), it is mentioned that the feed conversion was low although the growth rates of the pigs were maintained since the protein in the diet had to be reduced by $2 \%$.

As to the mortality rate, no loss of animals was recorded during the time the experiment was carried out.

\section{Conclusion}

Taking into account the results of this study on the productive parameters, it is evident that there is no negative effect on weight gain, accumulated feed intake, feed conversion ratio and mortality, thus oreganon can be used as a replacement alternative to antibiotic growth promoters, which are found in commercial feeds.

On the other hand, this report shows that the maximum inclusion percentage of $P$. amboinicus is not yet available, so further research should be carried out in which higher doses of the dehydrated product is included and a sensory analysis of the meat from the different treatments should be carried out jointly to determine a possible effect on the carcass.

Regarding the antibacterial response, it is clear that there is an effect on the total flora as well as on the total coliforms, in such a way that the higher the inclusion of $P$. amboinicus the greater the effect on the control of the microbial count (as $\mathrm{CFU})$, corroborating the action it has against coliforms. 


\section{Acknowledgment}

To the authorities of the Faculty of Agricultural Sciences of the Technical University of Machala for their continuous support to field research and a special thanks to Dr. Roberto A. Santacruz-Reyes, for his help in the revision and translation into English of this manuscript.

\section{Authors' Contribution}

Angel Roberto Sánchez Quinche: Principal investigator of the study.

Mayte Madelaine Vega Tinoco: Data registration (at the field) and writing of the manuscript.

Esmeralda Dioselina Pimbosa Ortiz: Writing of the manuscript.

Mercedes Milena Jordán Romero: Writing of the manuscript.

Jordy Daniel Cordovilla Loaiza: Writing the manuscript.

Ion Perez Baena: Data analysis.

\section{Ethics}

This study was approved by the Honorable Board of Directors of the Faculty of Agricultural Sciences of the Technical University of Machala as part of the Degree Projects for the year 2018, taking the Guide of Good Swine Practices (GPP), AGROCALIDAD-ECUADOR. Likewise, in the field study, the authors always worked under the principle of animal welfare, food and environmental safety, following the standards established by regional (UTMACH), national (AGROCALIDAD) and international (FAO, OIE and CODEX ALIMENTARIO) policies.

\section{References}

Aragadvay Yungán, R. G., Núñez-Torres, O. P., Velástegui-Espín, G. P., Villacís-Aldaz, L. A., \& Guerrero-López, J. R. (2016). Uso de harina de Colocasia esculeta L., en la alimentación de cerdos y su efecto sobre parámetros productivos. Journal of the Selva Andina Animal Science, 3(2), 98-104. doi.org/10.36610/j.jsaas.2016.030200098

Ardoino, S. M., Toso, R. E., Alvarez, H. L., Mariani, E. L., Cachau, P. D., Mancilla, M. V., \& Oriani, D. S. (2018). Antimicrobianos como promotores de crecimiento (AGP) en alimentos balanceados para aves: Uso, resistencia bacteriana, nuevas alternativas y opciones de reemplazo. Ciencia Veterinaria, 19(1), 50-66.

doi.org/10.19137/cienvet-20171914
Aroche, R., Martínez, Y., Ayala, L., Rodríguez, R., \& Rodríguez, Y. (2017). "Comportamiento productivo e incidencia de diarrea en cerdos posdestete suplementados con polvo mixto de hojas de plantas con propiedades nutraceúticas". Revista Ciencia y Agricultura, 14 (2), Colombia: 19 - 26. doi.org/10.19053/01228420.v14.n2.2017.7145

Ashaari, N. S., Ab. Rahim, M. H., Sabri, S., Lai, K. S., Song, A. A. L., Abdul Rahim, R., ... \& Ong Abdullah, J. (2020). Functional characterization of a new terpene synthase from Plectranthus amboinicus. PloS one, 15(7), e0235416. doi.org/10.1371/journal.pone.0235416

Ayala, L., Martínez, M., Acosta, A., Dieppa, O., \& Hernández, L. (2006). Una nota acerca del efecto del orégano como aditivo en el comportamiento productivo de pollos de ceba. Revista Cubana de Ciencia Agrícola, 40(4), 455-458.

https://www.redalyc.org/pdf/1930/193017672009.pdf

Baca, N., \& Ampuero, A. (2019). Efecto de la inclusión de aceite esencial de orégano en la dieta de lechones destetados sobre parámetros productivos. Revista de Investigaciones Veterinarias del Perú, 30(4), 1537-1542. doi.org/10.15381/rivep.v30i4.17145

Bencomo, B. G. (2010). Manejo sanitario eficiente de los cerdos. Instituto Nicaraguense de Tecnología Agropecuaria, INTA, Managua (Nicaragua); Instituto Nacional Tecnologico, Managua (Nicaragua). http://www.fao.org/3/as542s/as542s.pdf

Blanco-Roa, N., Hernández Zapata, S., Chavarría Rivaz, E., \& Zúniga-Gonzalez, C. A. (2019). Estimación in vivo de la canal porcina por el método de ultrasonografía: Un Enfoque de la Ecointensificación en Bioeconomia Porcina. Revista Iberoamericana De Bioeconomía Y Cambio Climático, 5(10), 1278-1294. doi.org/10.5377/ribcc.v5i10.8966

Blasco, A. (2010). Análisis de datos experimentales para proyectos fin de carrera. Universidad Politécnica de Valencia.

Caicedo, W., \& Flores, A. (2020). Características nutritivas de un ensilado líquido de banano orito (Musa acuminata AA) con tubérculos de taro (Colocasia esculenta (L.) Schott) y su efecto en cerdos de posdestete. Scielo. Rev. investig. vet. Perú, 31(1), 1-14. doi.org/10.15381/rivep.v31i1.17545

Caicedo, W., Alves, F., \& Caicedo, L. (2020). Efecto del ensilado de tubérculos de taro (Colocasia esculenta [L.] Schott) sobre indicadores productivos y reproductivos en cerdas F1 Landrace x Duroc. Scielo. Rev. investig. vet. Perú 31(2), 1-10. doi.org/10.15381/rivep.v31i2.17830 
Caicedo, W., Pérez, M., Sanchez, J., Flores, A., \& Duchitanga, E. (2019). Contenido de fenoles totales y actividad antioxidante del follaje de anís silvestre (Piper auritum Kunth) y su efecto nutracéutico para cerdos en posdestete. Revista de Investigaciones Veterinarias del Perú, 30(4), 1470-1480. doi.org/10.15381/rivep.v30i4.17264

Carrero, H. (2005). Manual de producción porcícola. Ministerio de protección social. Servicio Nacional de Aprendizaje SENA. Centro Latinoamericano. México. Pág, 113.

http://www.ciap.org.ar/Sitio/Archivos/Manual\%2 0de\% 20produccion\%20porcicola.pdf

Cheng, C., Xia, M., Zhang, X., Wang, C., Jiang, S., \& Peng, J. (2018). Supplementing oregano essential oil in a reduced-protein diet improves growth performance and nutrient digestibility by modulating intestinal bacteria, intestinal morphology and antioxidative capacity of growing-finishing pigs. Animals, 8(9), 159. doi.org/10.3390/ani8090159.

Chuanshang, C., Zhang, X., Xia, M., \& Zuhong, L. (2017, diciembre). Effect of oregano essential oil and benzoic acid supplementation to a low-protein diet on meat quality, fatty acid composition and lipid stability of longissimus thoracis muscle in pigs. Lipids in Health and Disease. Research Gate, 9. 10.1186/s12944-017-0535-1

Chuchuca, C. C., Quinche, Á. R. S., González, O. N. V., Flores, L. S. H., \& Guerrero, J. N. Q. (2016). Uso de Infusión de oreganón Plectranthus amboinicus (Lour.) Spreng y del vinagre en la crianza de pollos "Acriollados" (Gallus gallus domesticus) mejorados. Acta Agronómica, 65(3), 298-303. doi.org/10.15446/acag.v65n3.46222

Escobar, A., Perez, M., Romanelli, G., \& Blustein, G. (2020). Thymol bioactivity: A review focusing on practical applications. Arabian Journal of Chemistry. doi.org/10.1016/j.arabjc.2020.11.009

Espinoza, S., Icochea, E., Reyna, P., San Martín, V., Cribillero, N. G., \& Molina, D. (2019). Rendimiento productivo de pollos de engorde suplementados con tilosina fosfato o enramicina como promotores de crecimiento. Revista de Investigaciones Veterinarias del Perú, 30(1), 483-488. doi.org/10.15381/rivep.v30i1.15666

Flores Mancheno, L. G., García-Hernández, Y., Proaño-Ortiz, F. B., \& Caicedo-Quinche, W. O. (2015). Evaluación de tres dosis de un preparado microbiano, obtenido en Ecuador, en la respuesta productiva y sanitaria de cerdos en posdestete. Ciencia y Agricultura, 12(2), 59-70. doi.org/10.19053/01228420.4392
Guachamín, M., Vásquez, A., \& Olmedo, G. (2018). Digestibilidad aparente de dietas con dos niveles de intestinos cocidos de pollos en la alimentacion de cerdos. ecuador es calidad, 5(1). doi.org/10.36331/revista.v5i1.34

Gupta, S. K., \& Negi, P. S. (2016). Antibacterial Activity of Indian Borage (Plectranthus amboinicus Benth) Leaf Extracts in Food Systems and Against Natural Microflora in Chicken Meat. hrcak, 54, 90-102. doi.org/10.17113/ftb.54.01.16.3973

Languido, L. S., Marcos, M. J. L., \& Gaffud, O. M. (2020). Performance of Bounty Fresh Broiler Chicken Fed Diet Supplemented with Oregano (Plectranthus amboinicus L.) Leaf Meal. European Journal of Agriculture and Food Sciences, 2(2). doi.org/10.24018/ejfood.2020.2.2.24

Menendez Castillo, A., \& Pavón Gonzalez, V. (2018). Plecthranthus amboinicus (Lour.) Spreng. Revista Cubana de Plantas Medicinales, 4(3), 110-115.

Mernandez, G. L., Osorio Fortich, M. R., Torrenegra, M. E., \& Jesus Gil Gonzalez. (2015, octubre). Extracción, caracterización y actividad antioxidante del aceite esencial de plectranthus amboinicus L. Revista Cubana de Farmacia, 49(4).

Miranda-Yuquilema, J. E., Marin-Cárdenas, A., \& González-Pérez, M. (2018a). El comportamiento bioproductivo de cerdas reproductoras y su descendencia alimentadas con aditivo probiótico. Revista de Ciencias Agrícolas, 35(1), 69-81. doi.org/10.22267/rcia.183501.84

Miranda-Yuquilema, J. E., Marín-Cárdenas, A., Lazo-Pérez, L., \& Sánchez-Macías, D. (2018b). Repercusión de bacterias lácticas y levaduras sobre el comportamiento productivo y salud de lechones. Revista de Investigaciones Veterinarias del Perú, 29(4), 1203-1212. doi.org/10.15381/rivep.v29i4.15184

Paredes, M., Paico, V., Mantilla, J., \& Mustafa, A. (2020). Extracto de Macleaya cordata como uso alternativo a la bacitracina en lechones. Revista de Investigación de Agroproducción Sustentable, 4(2), 23-30. doi.org/10.25127/aps.20202.550

Pujada Abad, H., Vega-Vilca, J., Velásquez Vergara, C., \& Palacios-Rodríguez, B. (2019). Niveles de orégano (Origanum vulgare) en la dieta y su influencia en el rendimiento productivo del pollo de engorde. Revista de Investigaciones Veterinarias del Perú, 30(3), 1077-1082. doi.org/10.15381/rivep.v30i3.16599

Ribiero, F. A., de Morais, S. M., Nogueira, A. C., Goes da Silva, I. N., Martins, C. G., \& de Sousa Silva, A. A. (2018, marzo). Composição química atividades antioxidante e antifúngica dos óleos essenciais e extratos de "Plectranthus" spp. contra fungos dermatófitos. SciELO Brasil, 19(1). doi.org/10.1590/s1519-99402018000100010 
Tan, Z., Yang, T., Wang, Y., Xing, K., Zhang, F., Zhao, X., Ao, H., Chen, S., Liu, J., \& Wang, C. (2017). Metagenomic Analysis of Cecal Microbiome Identified Microbiota and Functional Capacities Associated with Feed Efficiency in Landrace Finishing Pigs. Front. Microbiol. 8:1546. doi.org/10.3389/fmicb.2017.01546

Urbano, M., \& Velásquez, C. (2020). Efecto del tipo de promotor de crecimiento sobre el rendimiento productivo en pollos de engorde, bajo condiciones de trópico. Peruvian Agricultural Research, 1(2), 35-39. doi.org/10.51431/par.v1i2.580
Xiao, Y., Kong, F., Xiang, Y., Zhou, W., Wang, J., Yang, H., Zhang, G., \& Zhao, J. (2018). Comparative biography of the gut microbiome between Jinhua and Landrace pigs. Sci Rep 8, 5985. doi.org/10.1038/s41598-018-24289-Z

Zhang, T., Zhou, Y. F., Zou, Y., Hu, X. M., Zheng, L. F., Wei, H. K., Giannenas, I., \& Jin, L. Z. (2015). Effects of dietary oregano essential oil supplementation on the stress response, antioxidative capacity and HSPs mRNA expresion of transported pigs. ELSERVIER. doi.org/10.1016/j.livsci.2015.05.037 